\title{
Participation of the nurse manager in the process of hospital accreditation
}

\author{
Participação do enfermeiro gerente no processo \\ de acreditação hospitalar \\ Participación del gerente enfermero en el proceso \\ de acreditación hospitalaria
}

\author{
Andréia Guerra Siman ${ }^{\mathrm{a}}$ \\ Maria José Menezes Brito ${ }^{b}$ \\ Melissa Evelyn Lopez Carrascoc
}

DOl: $\quad$ http://dx.doi.org/10.1590/1983-

1447.2014.02.44510

\footnotetext{
a Doctoral nursing student, Graduate Program in Nursing, School of Nursing, Federal University of Minas Gerais. Member of the Center for Research in Nursing Administration(NUPAE). Assistant Professor Federal University of Viçosa, Nursing Department. Viçosa, Minas Gerais. Brazil

b Post doctorate, Federal University of Santa Catarina. Associate Professor at EEUFMG. Applied Nursing Department. Director of NUPAE.

c Undergraduate in Nursing at EEUFMG.
}

\begin{abstract}
This study's aim was to understand the role of nurse managers in the process of hospital accreditation. This qualitative case study was conducted in a large private hospital in Belo Horizonte, MG, Brazil. Five nurse managers were interviewed using a semi-structured script from April to May, 2011 and content analysis was used to interpret the data. Results show the strategic position of this professional, his/her managerial skills and participation in the implementation and maintenance of accreditation, and the importance of care management. Nurses have played managerial roles with greater autonomy, connecting inter-sector care, which contrasts with the curative model, and have established partnerships with different social and institutional segments, adopting standards for teamwork. Managerial, healthcare, and educational work is performed from a procedural and indivisible perspective.
\end{abstract}

Descriptors: Accreditation. Management. Nursing.

\section{RESUMO}

Este estudo objetivou compreender a atuação do enfermeiro gerente no processo de acreditação hospitalar (AH). Trata-se de um estudo de caso qualitativo realizado em um hospital privado de grande porte em Belo Horizonte. Foram entrevistados cinco enfermeiros em cargos de gerentes, utilizado roteiro semiestruturado, no período de abril a maio de 2011, e a análise de conteúdo, para análise dos dados. Foi possível identificar a posição estratégica que o enfermeiro ocupa, a sua capacidade gerencial, a importância da gestão do cuidado e sua participação na implantação e manutenção da acreditação. 0 enfermeiro tem assumido funções gerenciais com mais autonomia, articulando uma assistência intersetorial, contrária ao modelo curativo, estabelecendo parcerias com diferentes segmentos sociais e institucionais e adotando padrões para o trabalho em equipe. 0 trabalho gerencial, assistencial e educacional é desenvolvido dentro de uma perspectiva processual e indissociável.

Descritores: Acreditação. Gerência. Enfermagem.

\section{RESUMEN}

El objetivo de ese estudio fue entender el papel de un gerente de enfermería en el proceso de acreditación de hospitales (AH). Este es un recorte de un estudio de caso cualitativo realizado en un hospital privado con semiestructura. Para ese artículo, se presentan los datos obtenidos mayormente de la categoría profesional de enfermeros. Fue posible identificar la posición estratégica que el profesional tiene, las herramientas que ha desarrollado para la evaluación de la asistencia y su papel fundamental en la implementación y mantenimiento de la Acreditación Hospitalaria. halos enfermeros han asumido funciones de administración con más autonomía, articulando una asistencia sectoria. Diferente del modelo curativo, estableciendo alianzas con las diferentes normas sociales e institucionales y adoptarlos en el trabajo en equipo. Sin embargo, había preocupaciones y dificultades con los detalles de la administración. La gestión, la atención y del trabajo educativo se desarrolla desde un punto de vista procesal y son inseparables.

Descriptores: Acreditación. Administración. Enfermería. 


\section{口INTRODUCTION}

Organizations in all economic sectors, and recently in the health field, have implemented efforts to improve quality through the development of assessment strategies, such as implementing hospital accreditation (HA). "Accreditation Programs" emerge with the proposition of improving care and the management of hospital facilities. The idea is to increase the likelihood of achieving the favorable results that comprise the binomial "assessment and education", characterized as a voluntary, periodic and reserved process intended to ensure quality of care through previously established standards. Standards may be minimal or more strict, defining different levels of satisfaction ${ }^{(1)}$.

The initiative to implement accreditation processes in Brazil in based on American experiences. Accreditation in health organizations originated in the United States when the American College of Surgeons (ACS) was created and established the Hospital Standardization Program in 1924. A set of appropriate standards was established to ensure quality of healthcare ${ }^{(2)}$. In this sense, the World Health Organization (WHO) recommends the adoption of accreditation programs.

In Brazil, the National Organization of Accreditation (ONA) was created in 1999. It is responsible for accreditation processes in the country and promotes a continuous process of education that is consolidated in the value assigned to a context given a reference or standard, followed by systematic assessment ${ }^{(1)}$. Avedis Donabedian developed attributes for understanding quality assessment in the field of health based on the concepts of structure, process and results ${ }^{(3)}$. The objective of the ONA's methodology is to implement a continuous assessment process and the certification of quality in health facilities, also based on the assessment of structure, process and results ${ }^{(1)}$.

Note that a concern with quality of care accompanies actions to ensure patient safety, an important national commitment and one of the focuses of $\mathrm{HA}$, in addition to the current priority of the $\mathrm{WHO}$ with the structuring of the National Program of Patient Safety (PNSP), a movement that establishes safety actions and international goals for healthcare facilities ${ }^{(4)}$. Recent studies ${ }^{(5-6)}$ addressing HA show that quality management contributes to increased financial efficiency and efficacy, the organization of processes, meeting the demands of clients, development, and employee satisfaction. One study seeking to identify the role of nurses in the HA process highlights positive aspects, such as personal growth and resumé valorization; however, it also reports negative aspects, such as stress and low professional valorization ${ }^{(6)}$. From this perspective, achieving accreditation requires effort on the part of nurses in managerial roles, who have the objective of encouraging the development of knowledge, competencies and skills. Nonetheless, studies addressing the role of nurse managers in institutions seeking certification in Brazil were not found.

Given the preceding discussion, the following concern is addressed in this study: what are the unique circumstances concerning the role of nurse managers working in hospital service in the accreditation process? It is believed that the participation of nurses is essential to achieving quality of care and institutional goals, requiring their direct participation in the organization of structure and safety, and in processes and results. Therefore, this study's objective was to understand the role of nurse managers in the HA process.

\section{口 METHOD}

This is a qualitative case study. Case studies are intended to investigate contemporary phenomena in their real context, enabling one to acquire broad and, at the same time, detailed knowledge, addressing the issues of how and why phenomena occur ${ }^{(7)}$.

This study was conducted in a large private hospital in Belo Horizonte, MG, Brazil. This hospital was accredited at the level of Excellence (ONA) in 2004. This facility was chosen because it was one of the first hospitals to be accredited at the level of Excellence in Belo Horizonte. The subjects were selected according to the inclusion criteria, that is, professionals who have worked in the facility and occupied managerial positions and participated in the accreditation process since its implementation. Therefore, the study's participants included all five of the nurses working in and occupying managerial functions in this hospital since the beginning of the accreditation process.

Data were collected from nurse managers through semi-structured interviews from April to May, 2011. The questions addressed aspects such as managerial activities and managerial actions performed during the accreditation process, as well as the role of nurses in this process and aspects that either facilitate or hinder the process.

Interviews were recorded after the participants consented, then were fully transcribed afterwards. Interviews are identified by the acronym NM (Nurse Manager) and numbered according to the order in which they occurred. Data were then submitted to content analysis in order to achieve a deeper understanding of the phenomenon and go beyond a merely descriptive report of the content man- 
ifested in the messages ${ }^{(8)}$. Data analysis was performed around three chronological divisions: pre-analysis, exploration of material, and treatment of results ${ }^{(8)}$.

All participants signed free and informed consent forms in accordance with resolution 466/12, Ministry of Health. The study was submitted to and approved by the Institutional Review Boards at the hospital and at the Federal University of Minas Gerais (UFMG), process No. ETIC 0611.0.203.000-10.

\section{RESULTS AND DISCUSSION}

Changes in management processes and care models have influenced health professionals' routines, especially those of nurses, who work in diverse functions and responsibilities, both in managerial and care roles.

This study's results indicate that nurses' knowledge and performance are essential to the process of $\mathrm{HA}$, since they assume strategic positions in health facilities and connect with other professionals, and also develop tools to assess care delivery, such as tactical actions. Nurses have played managerial roles at strategic, intermediate and operational levels, which confers on them more autonomy and greater participation in HA. Nurses stand out in the management of HA with great potential for the implementation, maintenance and development of quality policies. This is especially due to their managerial ability.

My work before the accreditation process was directed to managing service based on business management. It was a guideline from hospital $X$, so I already worked with indicators, planning, and the improvement process goes on, which you include and that matures this process with the coming of accreditation programs. We incorporate the method in our work to an even greater degree (NM2).

I supervise the assistance that supervisors provide in regard to administrative activities such as report analysis, or when insurance doesn't cover the costs due to some administrative error. So you make the plan of action, I'll give you some examples that I won't know how to explain, like special reports. The issue of personnel, hiring, assess the performance of employees, schedules, training, many meetings. With hospital accreditation, we manage to achieve a great deal of improvement. (NM4).

Historically and legally, management integrates the routine of nurses' work $k^{(9)}$. Currently, we see the professionalization of health management, which clarifies the duties and demands of clients and other professionals ${ }^{(10)}$.
Nobody achieves the objectives proposed by the quality system when working alone. For that, the professionals need to seek learning in other sciences. Seek to learn other concepts and work in an interdisciplinary manner, seeking in other fields the improvement of care (NM5).

This report indicates professional preparation for work within HA and the subjectivity of the managerial role marked by relationships among diverse actors involved in the processes. This role should be highlighted, since there are repercussions for institutions and professional staff. Considering, however, accreditation as a systemic process, involving professionals from diverse fields, and considering the attributes related to quality (efficacy, effectiveness, efficiency, optimization, acceptability, legitimacy, and equity $\left.{ }^{(11)}\right)$ facilitates understanding the interviewee reports, which indicates that the achievement of quality is something complex. The nurses identify HA as the consolidation of teamwork, in which achieving the objectives of improvement and care safety is impossible without this attribute. From this perspective, work in isolation and without cooperation makes achieving Excellence improbable.

We note that this tendency has been indicated in the adoption of standards directed to teamwork in the face of new models of management in health services ${ }^{(10)}$ and in accordance with the Systematization of Nursing Care (SAE) ${ }^{(12)}$. The following report reaffirms this:

Nurses do not work in isolation. Nursing is a center of reference for patient care. So, what happened is that with hospital accreditation we clarified this, we started showing many concepts, like the internal client, the client-provider chain. It was a gradual process. Today, after almost seven years of the accreditation program, we've matured a lot. If you get the accreditation process we experienced, we've come a long way, which has made the management even more complex (NM2).

Authors ${ }^{(12)}$ state that the work of nurse managers is based on a relationship of interdependence with the staff and other health professionals, because they work in an inter-sector fashion, establishing partnerships with different social and institutional segments, which transcend the specificity of the health sector. Nurses' work involves both direct and indirect care, characterizing a singular professional practice, which demands continuous improvement. To achieve quality care, a managerial inter-sector, interdisciplinary work style is required to encourage working toward integral care, breaking from the predominant biomedical 
and curative logic. In addition to the genuine need for teamwork, accreditation demands this work be enhanced.

Teamwork, however, represents a challenge due to the diversity of people and ideas in the face of a process of common work. It is necessary to understand the work process entirely and also the inter-relationships between its elements. It is worth noting that the more complex the work process, the less systematized it is and the harder it is to conceptualize it ${ }^{(13)}$.

Despite expertise in administration, nurses still experiences some difficulties:

People need to have knowledge in Administration, a factor that sometimes makes it difficult for nurses, for those who are in care delivery. Though most of the current programs address this topic (NM 2).

I don't have a background in business administration. So, for me it is difficult sometimes to control numbers, we keep working. Managers from other sectors in the hospital also help (NM 1).

They need to improve calculations, indicators, consumption, costs; this tendency is not new. Once there is a disposition in the field to update knowledge, this reflects a concern on the part of organizations to professionalize their managerial staff(10). In the $1990 s^{(14)}$, the objective of quality assurance programs was to renew organizational processes in the face of modern technologies and collaborate with the efficiency of productive practices.

The reports indicate the concern that managers have for the improvement of care quality based on the qualification of the managerial staff. From the perspective of the need to connect different types of knowledge, we stress the need to adopt new knowledge that has been incorporated as a way to introduce improvements in the work process and incrementally implement managerial strategies.

Note that the search for knowledge in care processes with an excessive valorization of the use of material technologies at the expense of non-material technologies impoverishes care delivery and limits more qualified actions ${ }^{(15)}$. Care should be a combination of hard, hard-light, and light technologies ${ }^{(16)}$. The author uses the term light technology as a way to act among workers and patients involved with the production of care. Technologies instantiated in instruments are identified as hard technologies. Technological knowledge is structured as light-hard technology ${ }^{(16)}$. The authors highlight care as a goal and work as strategic category, highlighting the subject as the purpose of this goal, that is, the object of the nurse's work is the subject of care ${ }^{(15-16)}$.
Another interesting aspect is the set of connections among care, management and education. Management is intimately related to care and vice versa, from a procedural perspective that is inseparable from the subject in which care is essential, especially in regard to HA and quality improvement. The interviewed nurses acknowledge that nursing is the heart of care delivery, configured as a link among care actions without untying management and care from one another.

\section{$[. .$.$] I try to get what is managerial, bureaucratic and bring$ it to care, improving care delivery (NM 5).}

[...] especially the nurse gives priority to care, and he thinks this thing bureaucracy is a pain "I won't fill out this bureaucratic thing", but the most important thing I do here, which is to encourage professionals to comply with formalities and the link among sectors is to ally care [... .] and what is really important is the relationship (NM1).

Nursing is a keystone and occupies a prominent place in the institution that is seeking to be accredited or to keep its accreditation.

The organization of care is essential. If you don't put the date on a bandage, if the nurse doesn't do her part, doesn't check medication, we can't get accreditation (NM 3).

Again, these reports refer to SAE because they cite the organization of care. SAE is one of the tools used in nurses' work processes that contributes to ensuring quality of care. It is not the totality of nursing care, because SAE refers to a range of instruments that includes communication, interaction, and connection between the care and managerial dimensions ${ }^{(12)}$. Another important aspect is patient safety, a priority in quality of care. Safety means to provide healthcare that is beneficial, without harm, reducing the risk to patients of complications.

Hence, nurses possess a diversity of competencies, knowledge and technical skills, contributing to the improvement of health services. A recent study addressing $H A$, highlights some of these skills, such as leadership, through which nurses provide safe and quality conditions for care, managerial actions related to the reorganization of work processes and continuous education ${ }^{(17)}$. When situating nursing as the central axis of care, it is essential to mobilize and link all these competencies in a way that leads to improved care.

Considering the attributes of quality ${ }^{(11)}$ and its pillars, i.e., structure, process and result ${ }^{(3)}$, in regard to structure, 
the institution needs to meet requirements like human resources, professional qualification, qualification of technicians and safe care ${ }^{(1)}$. According to the interviewees, nurses from an accredited facility have greater confidence in their work. In this sense, they highlight the fact that the work provided by these professionals has inherent risks, but when the work is developed in an accredited institution, these risks are managed. The reason is that these professionals seek improvement in processes, record activities and maintain documentation. A recent study also reports that Excellence in the care provided to patients is achieved with the standardization of techniques, based on scientific practice, directing action and heath practices performed in a safe manner ${ }^{(18)}$. Hence, HA through the ONA methodology, considers the safety of workers and patients ${ }^{(1)}$, which is shown in the following report:

After certification, everything else is more rational. There were [...] higher requirements; we manage our routine and the risk of our profession better. It also conferred safety on our work, brought the documentation and records necessary (NM1).

For the program, we have to record everything [...] it's not a very common practice. It wasn't a reality before. Nowadays, we keep better records, in a more organized way (NM2).

These improvements are translated into responsibility and quality, both directly linked to the search for knowledge ${ }^{(1)}$. Learning more about HA increases the responsibility of the professionals toward the patient, institution and even toward themselves.

It [accreditation] demands a lot of knowledge, not only from the manager, but from the nurses, as well. I've also improved my competencies as a manager. [...] Critical analyses we perform, each nurse is responsible for their own analysis, both from the point of view of care and from a managerial perspective, something we acquired over time. Nurses don't come with this ability from their education; they learn all this here(NM2).

It accrues from the process [...] It's clear that changes. Things change a lot in the health field and nursing. In recent years, it's changed the work of the nurse manager. But not only the work of the manager, but also of the nurse, of the nursing technician, it's changed the institution. I don't say this it is separated from the accreditation process, but I believe that it's inherent to the development itself, the complexity that the hospital has acquired, the health institution(NM1).

Understanding the role of the nurse manager within HA goes beyond improvement in care, it also includes managerial improvements. Despite the challenges that arise in the face of the new, nurses stand out in these roles by developing managerial competencies that are introduced during the undergraduate program. According to the interviewees, though, after entering the job market, there is a sense of shared responsibility in organizational and professional terms in their managerial development.

Some aspects that hinder this process were mentioned: lack of professional qualification; training that does not address accreditation programs; deficiency in the learning-teaching process, characterized by the dichotomy, already recognized, between "theory and practice".

Note that nursing is adapting to the propositions of reorganization of the institution, not only of the supplementary system, but the health system itself. The involvement of nurses with the institution, and changes in the way of organizing work processes can change the health system based on quality, reinforcing the need to construct a teaching-learning process that leads future professionals to develop specific competencies ${ }^{(19)}$. The need to reinforce the interaction between teaching and service emerges, solidifying a training process that acknowledges changes that take place with the implementation of new care and managerial models, which therefore, changes the work process in health and also requires change in professional profile, an education that aggregates skills for decision-making, communication, leadership, management and education.

The interviewees highlighted some managerial actions, which are seen as a possibility for growth, though at the same time, they generate insecurity:

For nurses to work in an accredited hospital, they have to have competence based on the managerial field, which is difficult because the education of nurses still has this gap. So, it was a very difficult process, of many changes, changes of culture, of the nursing staff working here. So, it is a construction; it was a construction (NM1).

An aspect that make things difficult is knowledge. If a manager doesn't have proper knowledge of the managerial process, of the administrative field, it's difficult to understand. You'll analyze an indicator, what is a standard deviation, what is a goal. So, like, people have to have knowledge of administration. It's a factor that sometimes makes things difficult for nurses (NM2). 
Another aspect refers to the professional development of nurses when involved with $\mathrm{HA}$, which enables them to have a clearer view of the institution, with greater autonomy and power to participate in decision-making at strategic levels. The conclusion drawn is that the accreditation process enhances managerial work. It is worth keeping in mind that the most important characteristic of the proposition of accreditation is to preserve the "assessment-education" binomial(1). Note that HA is mainly a proposition of continuous education that intends to ensure quality of care, generating a need for investment to enable changes in the processes of organization, meeting the demands that accrue from the certification. Hence, HA represents an important strategy of qualification.

We started participating in certain actions. We started participating in the company's financial health per se, we and the nurses [...] I guess that there was a radical change of attitude, of action, based on the concerns nurses had in regard to the company's administration. From then on, we kept improving from the administrative point of view, in regard to planning, relationships among professionals and among the teams (NM 1).

Improved communication, teamwork, self-assessment, review and internal decisions were identified before and after the assessment, in which nurses showed themselves to possess managerial competencies and skills.

\section{FINAL CONSIDERATIONS}

In the face of challenges regarding quality, nurses included in the HA process have a relevant role both in the process through with an institution acquires accreditation and how they keep the certifications they acquire. Nurses stood out as professionals able to establish cooperation and connections, with active participation in the organization's decision-making, essential for the institution to achieve its internal objectives. Interdisciplinary work, however, is essential to achieving quality care and encouraging teamwork with a view to provide integral care.

Nurses seek professional qualification at the graduate level to perform managerial functions, in addition to the learning they acquire within the organization itself. That is, the organization is partly responsible for the learning nurses acquire to develop their managerial role.

The methodology was appropriate and the objectives were achieved. In this sense, the specificities of the work nurses perform as managers in the hospital service are related to the strategic position they occupy and their abili- ty to connect with other professionals, and their ability to make organizational decisions because they understand the work process in its totality, perceiving the impossibility of working in isolation without cooperation. They develop strategies to cooperate and connect with different types of knowledge and different actors to concretize the objectives connecting management, care and education. From the perspective of managers, nurses are key, occupying a prominent position in the institution. Accreditation confers security and contributes to professional growth, the growth of the institution and also improves the quality of care in the institution in regard to patient safety. These changes should not remain isolated in private facilities, but should also be disseminated throughout the entire health system.

The nurses possess managerial skills and competencies that involve the planning of actions, leadership, communication and teamwork, all of which are appropriate given the proposition of reorganizing the institution and the health system, which favors HA. Considering that HA is an innovative strategy in Brazil, there is a limited amount of research addressing the role of nursing management in HA. There is a need to deepen this topic and study the context of other institutions.

\section{REFERENCES}

1. Organização Nacional de Acreditação (BR). Manual de organizaçōes prestadoras de serviços hospitalares. Braślia; 2010. p. 160.

2. Novaes HM. 0 processo de acreditação dos serviços de saúde. Rev Adm Saúde. 2007;9(37):133-40.

3. Donabedian A. The quality of care: how can it be assessed? JAMA. 1988;260(12):1743-8.

4. Agência Nacional de Vigilância Sanitária (BR). [Segurança do paciente e qualidade assistencial] Boletim Informativo Segurança do Paciente e Qualidade em Serviços de Saúde. 2011 jan-jul; 1(1):1-12.

5. Manzo BF, Ribeiro HCTC, Brito MJM, Alves M. As percepções dos profissionais de saúde sobre o processo de acreditação hospitalar. Rev Enferm UERJ. 2011;19(4):571-6.

6. Manzo BF, Ribeiro HCTC, Brito MJM, Alves M. A enfermagem no processo de acreditação hospitalar: atuação e implicações no cotidiano de trabalho. Rev Lat-am Enfermagem. 2012;20(1):151-8.

7. Yin RK. Estudo de caso: planejamento e métodos. 3a ed. Porto Alegre: Bookman; 2005.

8. Bardin L. Análise de conteúdo. Lisboa: Ediçōes 70; 2009.

9. Conselho Federal de Enfermagem (BR). Lei $7498 / 86$ de 25 de junho de 1986: dispõe sobre a regulamentação do exerćcicio da enfermagem, e dá outras providências. Brasilia; 1986.

10. Ribeiro de Brito AM, Menezes Brito MJ, Gazzinelli MFC, Montenegro LC. Representações sociais de discentes de graduação em enfermagem sobre "ser enfermeiro". Rev Bras Enferm. 2011 maio-jun [citado 2013 maio 10]; 64(3):527-35. Disponivel em: http://www.redalyc.org/articulo.oa?id=267019943017 
11. Donabedian A. The seven pillars of quality. Arch Pathol Lab Med. 1990;114(11):1115-8.

12. Torres E, Christovam BP, Fuly PCS, Silvino ZR, Andrade M. Sistematização da assistência de Enfermagem como ferramenta da gerência do cuidado: estudo de caso. Esc Anna Nery. 2011 out-dez;15(4):730-6.

13. Gonçalves, RBM. Práticas de saúde: processo de trabalho e necessidades. São Paulo: CEFOR, 1992.

14. Motta, Paulo R. Gestão contemporânea: a ciência e a arte de ser dirigente. Rio de Janeiro: Record; 1991.

15. Ramos FRS, Bertoncini JH, Machado RR, Flor RC, Pires DEP, Gelbcke FL. Trabalho, educação e política em seus nexos na produção bibliográfica sobre o cuidado. Texto Contexto Enferm. 2009;18(2):361-8.
16. Merhy EE, Franco TB. Por uma composição técnica do trabalho centrada no campo relacional e nas tecnologias leves: apontando mudanças para os modelos tecnoassistenciais. Saúde em Debate. 2003;27(65):316-23.

17. Manzo BF, Brito MJM, Corrêa AR. Implicações do processo de acreditação hospitalar no cotidiano de profissionais de saúde. Rev Esc Enferm USP. 2012;46(2):388-94

18. Manzo BF, Ribeiro HCTC, Brito MJM, Alves M, Feldman LB. As implicações do processo de acreditação para os pacientes na perspectiva de profissionais de enfermagem. Enfermeria Global. 2012;25:272-81.

19. Silva KL. Sena RR. A educação de enfermagem: buscando a formação crítico reflexiva e as competências profissionais. Rev Lat-am Enfermagem. 2006; 14(5):755-61.

\section{Author's address:}

Andréia Guerra Siman

Av. Peter Henry Rolfs, s/n, Campus Universitário,

Departamento de Enfermagem e Medicina

36570-000, Viçosa, MG

E-mail: ago.80@hotmail.com
Received: 07.01.2014

Approved: 07.05.2014 